\title{
FAKTOR PEMICU UTANG PEMERINTAH PROVINSI MALUKU UTARA PADA ANGGARAN 2018
}

\section{FACTORS OF NORTH MALUKU PROVINCIAL GOVERNMENT DEBT TRIGGERS IN BUDGET 2018}

\author{
Raoda M. Djae1, Rasid Poras ${ }^{2}$, Marno Wance ${ }^{3}$ \\ 1,2Universitas Muhammdiyah Maluku Utara, Indonesia \\ 3Universitas Pattimura, Indonesia \\ E-mail: raodamjae@gmail.com
}

\begin{abstract}
This study explains the factors of North Maluku government debt and its supervision on 2018 provincial budget. The purposes of this study are to analyze in depth about the factors that trigger the North Maluku government debt in the year 2018 and to analyze the form of regional budget supervision in 2018 fiscal year. In order to achieve the outlined objectives, this study was carried out for 3 (three) months to explore various data from various information related to the problems. This study type was qualitative with a descriptive analysis approach. The results of the study found that the North Maluku government debt from 2016 amounted to 412 billion. Financing costs are increasing in the line that the regional budget has not been able to carry out overall financing. Therefore, the government made debt to the third party for three years from 2016 to 2018 as many as 105 billion. The occurrence of debt irregularities was a result of weak budget management mechanisms. This was due to the budget management which was far from the principles of transparency and accountability required by applicable laws and regulations.
\end{abstract}

Keywords: Government Debt; Budget Planning; Financial Governance; Regional Budget Planning

\begin{abstract}
ABSTRAK
Penelitian ini menjelaskan tentang faktor pemicu utang pemerintah Provinsi Maluku Utara serta pengawasan APBD provinsi Maluku Utara Tahun anggaran 2018. Tujuan penelitian ini untuk menganalisa secara mendalam mengenai bagiamana faktor pemicu utang Pemerintah provinsi Maluku Utara tahun anggaran 2018 serta menganalis bentuk pengawasan APBD pada tahun anggaran 2018. Dalam rangka mencapai tujuan yang telah diuraikan, maka penelitian ini dirancang akan dilaksanakan selama 3 (tiga) bulan untuk menggali berbagai data dari berbagai informasi mengenai masalah penelitian ini. Jenis penelitian yang digunakan dengan jalan penelitian kualitatif dengan pendekatan
\end{abstract}


analisis deskriptif. Hasil penelitian menemukan bahwa pemicu utang Pemerintah Provinsi Maluku Utara dari tahun 2016 sebesar 412 milyar. Beban pembiayaan semakin besar sehingga APBD belum mampu melakukan pembiayaan secara keseluruhan. Oleh sebab itu, pemerintah melakukan utang kepada pihak ketiga selama tiga tahun yaitu 2016 sampai 2018 sebanyak 105 milyar. Terjadinya penyimpangan utang itu akibat dari lemahnya mekanisme pengelolaan anggaran. Sehingga menyebabkan pengelolaan anggaran jauh dari prinsip-prinsip transparansi dan akuntabilitas yang dipersyaratkan oleh peraturan perundang-undangan yang berlaku.

\section{Kata kunci: Utang Pemerintah; Perencanaan Anggaran; Tata Kelola Keuangan; Perencanaan APBD}

\section{PENDAHULUAN}

Pemerintah Provinsi Maluku Utara memiliki utang senilai Rp 412 M kepada pihak ketiga (www.brindonews.com). Terjadinya utang disebabkan oleh perencanaan asumsi pendapatan pemerintah provinsi tahun 2016 mencapai 2,7 triliun, namun target Anggaran Pendapatan Belanja Daerah (APBD) hanya 2,4 trilliun sehingga mengakibatkan pemerintah provinsi Maluku utara harus membebani anggaran pembangunan dengan melakukan utang ke pihak ketiga. Selisih defisit anggaran hampir setengah miliar harus dibebankan kepada APBD tahun anggaran 2017, mengakibatkan beban anggaran semakin besar di tahun berikutnya. Hal ini sebabkan oleh akibat tata kelola keuangan yang kurang baik sehingga beban anggaran daerah terus berlanjut dari tahun 2017 ke 2018. Berdasarkan hasil audit oleh Badan Pemeriksan Keuangan (BPK) bahwa pemerintah membayar lebih kepada pihak ketiga sebesar 105 miliar di tahun 2017. Akibatnya Pemerintah Provinsi Maluku Utara membebani utang kurang lebih setengah trilliun dari tahun 2017 ke 2018.

Diselenggarakan rapat paripurna Dewan Perwakilan Rakyat Daerah (DPRD) Provinsi Maluku Utara yang dilaksanakan pada tanggal 10 Maret 2018 di kantor DPRD Maluku Utara. Adapun agenda penyampaian Laporan Keterangan Pertanggung Jawaban (LKPJ) oleh Plt. Gubernur Provinsi Maluku Utara dan pembahasan Pemeriksaan Dengan Tujuan Tertentu (PDTT) Badan Pemeriksa 
Keuangan (BPK) oleh Pansus. Rapat paripurna tersebut berlangsung selama kurang lebih 4 jam, dimulai pada pukul 11.00 sampai dengan 14.30 WIT, dipimpin oleh Zulkifli Hi. Umar. Sedangkan perwakilan pansus PDKTT BPK di wakili sekretaris yaitu Syachril Marsaoly. Terdapat 8 poin penting hasil pembahasan pansus PDTT BPK, diantaranya (www. i-malut.com).

1) Terdapat kelebihan pembayaran pada sejumlah Organisasi Perangkat Daerah (OPD), Pansus merekomendasikan kepada Pimpinan DPRD agar mendesak kepada gubernur agar menginstruksikan kepada Tim Tindak Lanjut untuk mempercepat penyelesaian dan mempertanggungjawabkan kelebihan pembayaran pengembalian sebelum 60 (enam puluh) hari.

2) Diketahui bahwa BPK merekomendasikan kepada gubernur untuk memberikan sanksi sesuai ketentuan yang berlaku kepada sekretaris daerah, PPK, PPTK dan PPHP, serta pengenaan sanksi dalam daftar hitam kepada rekanan (kontraktor) yang bermasalah. Pansus merekomendasikan kepada Pimpinan DPRD untuk meminta kepada gubernur agar secepatnya menindaklanjuti rekomendasi BPK dimaksud dalam waktu sebelum 60 (enam puluh) hari.

3) Terdapat kelemahan pengendalian dalam hal kebijakan dan prosedur atas belanja barang jasa dan belanja modal yaitu Pemerintah Provinsi Maluku Utara belum mempunyai kebijakan terkait keterlambatan penyelesaian pekerjaan yang melewati tahun anggaran. Hal tersebut berakibat tidak adanya keseragaman perlakuan atas pekerjaan-pekerjaan yang melewati tahun anggaran. Terhadap hal ini Pansus merekomendasikan kepada Pimpinan DPRD untuk mendesak Gubernur untuk membuat Peraturan Daerah dan Peraturan Gubernur sebagai instrumen kebijakan terkait dengan pelaksanaan jasa konstruksi di Maluku Utara.

4) Diketahui terdapat pemutusan kontrak tiga paket pekerjaan yaitu pembangunan jaringan telekomunikasi di kabupaten Pulau Taliabu, 
pembangunan jaringan telekomunikasi di Kabupaten Halmahera Utara dan pembangunan menara Masjid Raya Al Munawwar Ternate tidak sesuai dengan ketentuan perundang-undangan. Pansus merekomendasikan kepada Pimpinan DPRD untuk meminta kepada gubernur untuk mempertanggungjawabkan kelebihan pembayaran atas tiga paket pekerjaan tersebut dan memberikan sanksi kepada Dinas Perhubungan dan Dinas PUPR.

5) Diketahui defisit APBD tahun anggaran 2016 dan 2017 melebihi batas maksimal defisit yang dipersyaratkan, sementara kemampuan penerimaan pembiayaan daerah dipastikan tidak dapat membiayai defisit APBD sehingga berpotensi terjadinya siklus utang daerah yang tidak berkesudahan. Untuk menyelesaikan masalah ini, Pansus merekomendasikan kepada Pimpinan DPRD untuk berkoordinasi dan minta petunjuk di Kementerian Keuangan dan Kementrian Dalam Negeri RI.

6) Diketahui bahwa pembayaran utang pihak ketiga tahun 2016 melalui perubahan Pergub tentang penjabaran APBD 2017 dilakukan sebelum pengesahan APBD 2017. Hal ini bertentangan dengan Permendagri nomor 31 tahun 2016 Tentang Pedoman Penyusunan APBD 2017, Pansus merekomendasikan kepada Pimpinan DPRD agar meminta kepada pemerintah daerah untuk menjelaskan kebijakan pembayaran utang yang tidak sesuai peraturan perundang-undangan.

7) Terdapat perbedaan jumlah nilai utang pihak ketiga yang disajikan dalam laporan keuangan tahun 2016 dengan jumlah utang berdasarkan hasil sensus Inspektorat Provinsi Maluku Utara, maupun jumlah utang yang telah dibayarkan, Pansus merekomendasikan kepada Pimpinan DPRD untuk meminta BPK melakukan pemeriksaan lanjutan agar memastikan nilai utang yang sebenarnya. 
8) Ditemukan lima belas (15) paket kegiatan yang tidak dianggarkan dalam APBD 2016 dan tidak ditenderkan, serta terdapat perbedaan nilai pagu anggaran antara APBD Perubahan 2016 dengan nilai kontrak dan nilai utang sesuai hasil sensus Inspektorat, tetapi diakui sebagai utang senilai Rp. 45.728.055.901,-(empat puluh lima miliar tujuh ratus dua puluh delapan juta lima puluh lima ribu sembilan ratus satu rupiah).

Atas sejumlah masalah tersebut, menurut Syachril, Pansus PDTT BPK telah meminta penjelasan Kepala Inspektorat Malut, Bambang Hermawan untuk memberikan klarifikasi, namun yang bersangkutan menjelaskan bahwa yang berkompeten untuk menjelaskan permasalahan ini adalah Kepala BPKPAD, Ahmad Purbaya. Namun setelah diundang sebanyak lima kali rapat, Kepala BPKPAD tidak pernah mengindahkan undangan Pimpinan DPRD.

Syachril yang juga sebagai ketua Komisi III DPRD Malut ini mengatakan, sebagai tindak lanjut dari hasil pembahasan, Pansus PDTT BPK telah merekomendasikan kepada Pimpinan DPRD untuk ditindaklanjuti. Poin rekomendasinya antara lain:

1. Meminta kepada Gubernur Malut untuk memberikan teguran keras kepada saudara Kepala Inspektorat, Bambang Hermawan dan Kepala BPKPAD, Ahmad Purbaya

2. Meminta BPK untuk melakukan pemeriksaan lanjutan dan/atau pemeriksaan investigatif.

Dari latar belakang di atas maka sangat menarik untuk melakukan riset tentang faktor apa saja yang menjadi pemicu terjadinya utang pemerintah provinsi pada anggaran 2018. Serta melihat sejauh mana proses perencanaan APBD tahun anggaran 2018. Perencanaan anggaran sangat penting dilakukan oleh pemerintah provinsi bersama dengan DPRD untuk mampu menekan beban pembiayaan serta utang. Oleh karena sangat menarik untuk melakukan riset terkait selanjutnya. Hasil penelitian yang dilakukan oleh Marno dan Suranto 
(2016) bahwa Pihak Pemerintah Kabupaten Buru Selatan (eksekutif) pada pembahasan KUA dan PPAS pada umumnya bersifat koersif di mana masingmasing SKPD memiliki kewenangan di fungsi penganggaran.Sementara, pola relasi perilaku ofensif lebih ditonjolkan ketika telah berdialog secara bersama dengan institusi DPRD (Legislatif) untuk membahas mulai pada penyusunan rancangan maupun perumusan APBD Kabupaten Buru Selatan (Marno \& Suranto, 2016:139). Selain itu, Hasil penelitian Marno (2017), Pola hubungan pemerintah daerah (eksekutif) dan DPRD (Legislatif) yaitu sangat diperlukan kordinasi antara lembaga, peningkatan inovasi SKPD dan Badan Anggaran (Banggar) dalam melakukan penyusunan program kerja di masing-masing SKPD dan mampu meformulasikan segala usulan melalui forum Musrembang maupun masa reses yang di lakukan oleh legislatif (Marno, Politik Anggaran Eksekutif dan Legislatif Pada Pembahasan APBD Buru selatan 2015, 2017:201)

\section{METODE PENELITIAN}

Penelitian ini menggunakan pendekatan kualitatif, sedangkan untuk memenuhi standar analitiknya berbentuk deskriptif. Bogdan dan Taylor, memandang pendekatan kualitatif sebagai prosedur penelitian yang menghasilkan data deskriprttif berupa kata-kata tertulis, lisan dan juga perilaku dari orang-orang yang diamati (Moleong, 1994). Pendekatan kualitatif dianggap lebih tepat dikarenakan tujuan dari penelitian ini adalah untuk mendeskripsikan praktek pemicu utang Pemerintah Provinsi Maluku Utara pada Anggaran 2018

Teknik penentuan informan dalam penelitian ini dilakukan secara purpossive. Menurut Kriyantono, purposive merupakan teknik yang meliputi orang yang diseleksi atas dasar tolak ukur tertentu yang dibuat oleh peneliti berdasarkan tujuan penelitian (Kriyantono, 2007). Adapun subyek atau informan penelitian adalah informan utama yakni Gubernur Maluku Utara, 
Badan Pemeriksan Keuangan (BPK) perwakilan Provinsi Maluku Utara, DPRD Provisni Maluku.

\section{HASIL DAN PEMBAHASAN}

\section{Fungsi Pengawasan DPRD: Tata Kelola Perencanaan APBD Provinsi}

\section{Maluku Utara}

Munculnya Trias Politika telah menciptakan pemisahan pada structural politik antara kekuasaan eksekutif, legislatif dan yudikatif. Melalui pemisahan itu kemudian muncul fungsi dari masing-masing bidang pemerintahan tersebut. Pengawasan merupakan fungsi yang muncul dari hasil pembagian kekuasaan tersebut yang melekat pada aparatur pemerintah untuk mewujudkan suatu pemerintahan yang berorientasi pada kesejahteraan rakyat. (Mardiasmo, 2001:205). Keberadaan Badan Legislatif didaerah (DPRD) merupakan bentuk terwujudnya demokrasi secara universal. Peran dan fungsi DPRD sebagai

penyeimbang kekuasaan pemerintah terdapat pada ketiga fungsinya yakni, fungsi legislasi, budgeting (anggran), dan controling (pengawasan). DPRD sebagai bentuk dari reprensentasi kekuasaan rakyat dalam membuat UndangUndang serta menjalakan semua fungsinya harus mencerminkan keberpihakannya kepada rakyat. Sehingga fungsi pengawasan yang dilakukannya menjadi sangat penting dalam proses pelaksanaan UndangUndang (perda) dan pengelolaan anggaran. (Sadu \& Riyani, 2003:93).

Dalam UU No. 23 Tahun 2014 tentang Pemerintah Daerah Bab I dijelaskan bahwa DRPD merupakan bagian dari unsur penyelenggara Pemerintah Daerah. Sehingga dengan posisi demikian DPRD harus membantu mendukung program dari Pemerintah Daerah. Melalui fungsi dan tugas yang sudah melekatlah DPRD menjalankan fungsinya sebagai unsur dari penyelengara Pemerintah Daerah. Pemerintah Daerah adalah kepala daerah sebagai unsure penyelenggara Pemerintahan Daerah yang memimpin pelaksanaan urusan pemerintahan yang 
menjadi kewenangan daerah otonom. Dewan Perwakilan Rakyat Daerah yang selanjutnya disingkat DPRD adalah lembaga perwakilan rakyat daerah yang berkedudukan sebagai unsur penyelenggara Pemerintahan Daerah.

\section{Fungsi DPRD: Mekanisme Pengawasan dan Strategi Pengawasan}

Pengawasan yang dilakukan DPRD merupakan yang ditetapkan oleh Undang-Undang, pengawasan dimaksudkan agar dalam pelaksanaan APBD yang dilakukan oleh eksekutif tidak terjadi penyimpangan dan penyalahgunaan dana APBD. Pengawasan DPRD merupakan tindakan pencegahan, tindakan korektif, serta tindakan evaluasi. Pengawasan ini dilakukan DPRD Provinsi Maluku Utara sejak para anggota dewan dilantik.

Kegiatan-kegiatan DPRD dalam kerangka pengawasan daerah mengikut berbagai mekanisme. Pertama, jenis-jenis rencana daerah yang meliputi pengawasan terhadap APBD pada akhir tahun anggaran, dan pengawasan terhadap RENSTRA unit kerja dijalankan hanya pada kegiatan atau program yang dananya bersumber pada APBD. Kedua, macam kegiatan daerah yang pengawasannya ditunjuka pada kegiatan-kegiatan dalam kerangka desentralisasi. Selain itu, pengawaan DPRD pada kegiatan-kegiatan dalam kerangka pelaksanaan desentralisasi.

\section{a. Tahap Perencanaan}

Penguatan tugas dan fungsi DPRD merupakan salah satu agenda pemerintah untuk dapat mewujudkan desentralisasi. Semenjak adanya otonomi daerah, maka tanggungjawab yang dibebankan kepada daerah atas keberlangsungan kehidupan di setiap daerah menjadi lebih besar, sehingga diharapkan DPRD dapat lebih berperan yang sebelum adanya otonomi peran DPRD sangat terbatas. Sekretariat DPRD merupakan SKPD yang berperan dan membantu DPRD dalam menjalankan tanggung jawab dan fungsinya tersebut. Oleh sebab itu, secretariat DPRD dalam menentukan perencanaan program pun harus dapat menyesuaikan dengan kebutuhan DPRD. 
Sebagaimana diatur dalam undang-udang Nomor 23 Tahun 2014 Pasal 152 mengenai fungsi anggaran yang berbunyi Fungsi anggaran sebagaimana dimaksud dalam Pasal 149 ayat (1) huruf b diwujudkan dalam bentuk pembahasan untuk persetujuan bersama terhadap Rancangan Perda Kabupaten/Kota tentang APBD Kabupaten/Kota yang diajukan oleh bupati/wali kota. Ayat ke (2) Fungsi anggaran sebagaimana dimaksud pada ayat (1) dilaksanakan dengan cara:

1. Membahas KUA dan PPAS yang disusun oleh bupati/wali kota berdasarkan RKPD.

2. Membahas rancangan perda kabupaten/kota tentang apbd kabupaten/kota

3. membahas rancangan Perda Kabupaten/Kota tentang perubahan APBD kabupaten/kota; dan

4. Membahas rancangan Perda Kabupaten/Kota tentang pertanggungjawaban pelaksanaan APBD kabupaten/kota (UU No 23, 2014:152).

\section{b. Tahap Pelaksanaan}

Pelaksanaan anggaran sepenuhnya menjadi tanggungjawab kepala SKPD untuk dapat mempertanggungjawabkan kepada Kepala Daerah. Permendagri No. 21 tahun 2011 tentang perubahan kedua atas permendagri No. 13 tahun 2006 tentang pedoman pelaksanaan keuangan daerah Pasal 122 Ayat 5 disebutkan bahwa jumlah belanja yang dianggarkan dalam APBD merupakan batas tertinggi untuk setiap pengeluaran belanja daerah (PP No 21, 2011).

\section{Peran Badan Pemeriksanaan Keuangan}

Keuangan Negara berperan penting dalam mewujudkan tujuan bernegara, yaitu melindungi segenap bangsa Indonesia dan seluruh tumpah darah Indonesia, memajukan kesejahteraan umum, mencerdaskan kehidupan bangsa, dan ikut serta melaksanakan ketertiban dunia yang berdasarkan keadilan, 
perdamaian abadi dan keadilan sosial. Untuk mewujudkan tujuan di atas, perlu dibangun suatu sistem pengelolaan keuangan negara yang bertumpu pada prinsip-prinsip ketertiban, ketaatan terhadap peraturan perundang-undangan, efisiensi, ekonomis, efektif, transparan dan akuntabel. Bagian dari sistem pengelolaan keuangan negara adalah sistem pengawasan dan pemeriksaan untuk memastikan bahwa keuangan negara telah dilaksanakan sesuai target dan tujuan yang hendak dicapai dengan mentaati peraturan perundang-undangan yang berlaku Tanggung jawab keuangan negara adalah kewajiban pemerintah dan lembaga negara lainnya untuk melaksanakan pengelolaan keuangan negara secara tertib, taat pada peraturan perundang-undangan, efisien, ekonomis, efektif, dan transparan dengan memperhatikan rasa keadilan dan kepatutan (Ikhwan, 2016). Keuangan Negara harus dipertanggungjawabkan oleh pemerintah sebagai pemegang kekuasaan pengelola keuangan negara kepada DPR/DPRD sebagai representasi rakyat dan kepada masyarakat sebagai pemilik kedaulatan melalui keterbukaan akses masyarakat terhadap informasi dan segala macam yang berkaitan dengan keuangan Negara (Ikhwan, 2016). Sebagaimana diamanahkan dalam Pasal 23 UUD 1945 perubahan ketiga, yaitu:

"Anggaran pendapatan dan belanja negara sebagai wujud dari pengelolaan keuangan negara ditetapkan dengan undang-undang dan dilaksanakan secara terbuka dan bertanggung jawab untuk sebesar-besar kemakmuran rakyat."

Agar segala kekurangan dalam laporan keuangan pemerintah dapat dideteksi secara akurat sebagai bahan dalam memperbaiki sistem pengelolaan dan tanggung jawab keuangan negara serta sebagai bahan dalam pengambilan kebijakan secara tepat, maka diperlukan satu lembaga negara khusus yang independen, obyektif, dan tidak memihak untuk memeriksa laporan keuangan pemerintah tersebut. Oleh karena itu, diperlukan suatu lembaga pemeriksa untuk mendukung keberhasilan penyelenggaraan pemerintahan negara yang bebas, mandiri, dan profesional sehingga dibentuklah suatu lembaga negara 
yaitu Badan Pemeriksa Keuangan yang selanjutnya disingkat BPK adalah lembaga negara yang bertugas untuk memeriksa pengelolaan dan tanggung jawab keuangan negara sebagaimana dimaksud dalam Undang-Undang Dasar Negara Republik Indonesia Tahun 1945 (BPK, Badan Pemeriksa Keuangan RI, 2017).

\section{Jenis Pemeriksaan Oleh Badan Pemeriksa Keuangan}

Pemeriksaan merupakan salah satu bagian dari pengawasan. Pengawasan sendiri bertujuan untuk memperoleh kepastian apakah pelaksanaan suatu pekerjaan atau kegiatan itu dilakukan sesuai dengan rencana, aturan-aturan dan tujuan yang telah ditetapkan. Pengawasan pada dasarnya adalah untuk mengamati apa yang sungguh-sungguh terjadi serta membandingkannya dengan apa yang seharusnya terjadi (Ikhwan, 2016). Bila tujuan pengawasan diterapkan terhadap pengawasan keuangan negara, maka tujuan pengawasan keuangan negara pada dasarnya adalah:

1. Untuk menjaga agar anggaran yang disusun benar-benar dapat dijalankan.

2. Untuk menjaga agar kegiatan pengumpulan penerimaan dan pembelanjaan pengeluaran negara sesuai dengan anggaran yang telah digariskan; dan

3. Untuk menjaga agar pelaksanaan APBN benar-benar dapat dipertanggungjawabkan.

Dalam konteks keuangan negara, pemeriksaan bertujuan untuk menilai dan menguji melalui bukti-bukti yang kompeten dan cukup apakah pelaksanaan pengelolaan keuangan negara oleh pemerintah telah dilaksanakan. Berdasarkan Pasal 4 UU Nomor 15 Tahun 2004 tentang Pemeriksaan dan Pengelolaan Tanggung Jawab Keuangan Negara, jenis pemeriksaan keuangan negara meliputi pemeriksaan keuangan, pemeriksaan kinerja, dan pemeriksaan dengan tujuan tertentu (PDTT). Tujuan pemeriksaan keuangan bertujuan untuk memberikan 
opini atas kewajaran laporan keuangan. Tujuan pemeriksaan kinerja adalah memberikan kesimpulan atas aspek ekonomi, efisiensi dan/atau efektivitas pengelolaan keuangan negara, serta memberikan rekomendasi untuk memperbaiki aspek tersebut. PDTT bertujuan untuk memberikan kesimpulan sesuai dengan tujuan pemeriksaan yang ditetapkan. PDTT dapat berbentuk pemeriksaan kepatuhan dan pemeriksaan investigative (BPK, 2017).

Pemeriksaan atas laporan keuangan bertujuan untuk menilai kewajaran penyajian laporan keuangan sesuai standar akuntansi pemerintahan (SAP). Kata kuncinya adalah "kewajaran". Wajar artinya laporan keuangan tersebut secara umum pencatatannya sudah sesuai SAP. Kewajaran tidak sama dengan kebenaran eksak. SAP mengatur antara lain kapan suatu transaksi dicatat dengan nilai berapa, dan informasi apa saja yang harus diungkapkan. Jika laporan keuangan secara keseluruhan sudah disajikan sesuai SAP, BPK akan memberikan opini WTP. Namun, jika sudah sesuai SAP tetapi ada pos-pos tertentu yang belum sesuai, BPK akan memberikan opini WDP. Jika secara keseluruhan laporan keuangan tidak disajikan sesuai dengan SAP, opininya TW. Dalam keadaan tertentu, jika auditor dibatasi aksesnya oleh manajemen untuk memeriksa dokumen yang diperlukan atau kondisinya sedemikian lemah di mana catatan-catatan keuangan sangat tidak bisa diandalkan (BPK, Badan Pemeriksa Keuangan, Korupsi Tidak Wajar, Tanpa Pengecualian, 2012).

Meskipun secara umum kualitas LKPD Tahun 2017 mengalami peningkatan dibanding LKPD Tahun 2016, tetapi terdapat 14 dari 542 (3\%) LKPD yang mengalami penurunan opini. Penurunan opini tersebut lebih rendah 2 poin persen dari penurunan opini tahun 2016 sebesar 5\% (25 dari 542 LKPD). Daftar pemda yang mengalami penurunan opini disajikan pada Tabel 1 di bawah ini. 
Tabel 1.

Daftar Pemerintah Daerah yang Mengalami Penurunan Opini

\begin{tabular}{|c|c|}
\hline \multicolumn{2}{|c|}{ Opini WTP Menjadi WDP } \\
\hline 1. Pemprov Maluku Utara & 7. Pemkab Sumba Timur \\
\hline $\begin{array}{l}\text { 2. Pemkab Penukal Abab } \\
\text { Lematang Hilir }\end{array}$ & $\begin{array}{l}\text { 1. Pemkab Hulu Sungai } \\
\text { Tengah }\end{array}$ \\
\hline 3. Pemkab Kaur & Pemkab Kutai Kartanegara \\
\hline 4. Pemkab Lampung Tengah & Pemkab Morowali \\
\hline 5. Pemkab Bangka Barat & Pemkab Kantingan \\
\hline 6. Pemkab Lumajang & Pemkab Tebing Tinggi \\
\hline \multicolumn{2}{|c|}{ Opini WDP Menjadi TMP } \\
\hline 1. Pemkab Simalungun & 2. Pemkab Morowali Utara \\
\hline
\end{tabular}

Sumber: Badan Pemeriksa Keuangan (BPK) Perwakilan Provinsi Maluku Utara, 2019

Laporan Hasil Pemeriksaan Atas Kinerja Memuat Temuan, Kesimpulan, dan Rekomendasi

Kesimpulan merupakan jawaban atas pencapaian tujuan pemeriksaan. Kesimpulan harus dinyatakan secara jelas dan meyakinkan. Kekuatan kesimpulan ditentukan oleh bukti yang meyakinkan dan didukung dengan metodologi yang tepat. Pemeriksa harus mengungkapkan temuan dalam LHP apabila terdapat ketidaksesuaian antara kondisi dengan criteria (BPK, Badan Pemeriksa Keuangan, Lampiran IV Peraturan BPK RI Nomor 1 Tahun 2017 Standar Pemeriksaan Keuangan Negara PSP 300, 15).

Temuan pemeriksaan yang mengandung indikasi awal kecurangan disajikan dalam LHP tanpa menjelaskan secara mendetail dugaan kecurangan tersebut. Namun Pemeriksa lebih menitikberatkan penjelasannya kepada dampak temuan tersebut terhadap hal pokok/informasi hal pokok sesuai tujuan pemeriksaan. 
Rekomendasi adalah saran dari pemeriksa berdasarkan hasil pemeriksaannya, yang ditujukan kepada orang dan/atau badan yang berwenang untuk melakukan tindakan dan/atau perbaikan. Rekomendasi pemeriksaan harus bersifat konstruktif dan berguna untuk memperbaiki kelemahankelemahan yang ditemukan dalam pemeriksaan. Pemeriksa wajib memberikan rekomendasi dalam pemeriksaan kinerja. Dalam pemeriksaan selain pemeriksaan kinerja, apabila Pemeriksa dapat mengembangkan temuan pemeriksaan secara memadai, Pemeriksa dapat membuat rekomendasi. Khusus pada PDTT dalam bentuk pemeriksaan investigatif, Pemeriksa tidak memberikan rekomendasi (BPK, Badan Pemeriksa Keuangan, Korupsi Tidak Wajar, Tanpa Pengecualian, 2012).

Tabel 2.

Temuan BPK Pada APBD Maluku Utara

\begin{tabular}{|c|c|c|c|}
\hline No & \multicolumn{1}{|c|}{ Permasalahan } & $\begin{array}{c}\text { Jumlah } \\
\text { Permasalhan }\end{array}$ & $\begin{array}{c}\text { Nilai } \\
\text { (Rp } \\
\text { miliar) }\end{array}$ \\
\hline $\begin{array}{l}\text { Kelebihan pembayaran yang terjadi pada } \\
\text { Pemprov Maluku Utara, namun atas } \\
\text { pekerjaan tersebut belum dilakukan } \\
\text { pelunasan pembayaran kepada rekanan, }\end{array}$ & 3,58 \\
yaitu: & \\
Pembangunan irigasi dan jaringan pada \\
PUPR dan Dinas Perumahan dan \\
Kawasan Pemukiman (PKP) senilai \\
Rp3,01 miliar. \\
Pembangunan gedung dan bangunan, \\
antara lain pembangunan rumah dinas \\
PNS Provinsi, pembangunan lanjutan \\
rumah adat Malifut Kabupaten \\
Halmahera Utara, dan pembangunan \\
Gedung PKK Provinsi Maluku Utara \\
senilai Rp499,72 juta. \\
Pengadaan bibit pala di Kabupaten \\
Pulau Taliabu dan pengadaan bibit \\
cengkeh di Kabupaten Halmahera Timur
\end{tabular}

Journal of Governance and Local Politics (JGLP)

ISSN (online): 2684-9992, Vol. 1, No. 2, November 2019 


\begin{tabular}{|l|l|l|l|}
\hline & \multicolumn{2}{|c|}{ senilai Rp69,38 juta. } & 1 \\
\hline & Kekurangan penerimaan atas penggunaan & 1,87 \\
langsung penerimaan Pajak Kendaraan & & \\
Bermotor (PKB) dan Bea Balik Nama & & \\
Kendaraan Bermotor (BBNKB) pada Pemprov & & \\
Maluku Utara sebesar Rp1,87 miliar. & & \\
\hline
\end{tabular}

Sumber: Badan Pemeriksa Keuangan (BPK) Perwakilan Provinsi Maluku Utara, 2019

Struktur Anggaran Pendapatann Belanja Daerah Maluku Utara

Anggaran pendapatan Pemprov Maluku Utara dalam APBD 2017 adalah sebesar Rp2,86 triliun atau meningkat 27,80\% dari anggaran pendapatan APBD 2016 yang tercatat sebesar Rp2,24 triliun (Tabel 2.1). Sementara itu, anggaran belanja Pemprov Maluku Utara dalam APBD 2017 ditetapkan sebesar Rp 2,51 triliun atau meningkat 7,66\% dari anggaran belanja APBD 2016 yang tercatat sebesar Rp 2,34 triliun (Tabel 2.1). Berdasarkan penetapan dari DPRD Maluku Utara tanggal 12 Januari 2017, APBD Provinsi Maluku Utara ditetapkan surplus Rp 215 miliar. APBD tersebut mengalami penyesuaian dengan rincian sebagai berikut:

Tabel 3.

APBD Maluku Utara 2017

\begin{tabular}{|c|c|c|c|}
\hline \multicolumn{4}{|c|}{ Jumlah (Rp) } \\
\hline Uraian & APBD 2016 & APBD 2017 & Perubahan \\
\hline Pendapatan & 2.241 .173 .725 .000 & 2.864 .175 .974 .702 & $27.80 \%$ \\
\hline $\begin{array}{c}\text { Pendapatan Asli } \\
\text { Daerah }\end{array}$ & 282.996 .628 .000 & 486.709 .146 .169 & $71.98 \%$ \\
\hline $\begin{array}{c}\text { Pendapatan } \\
\text { Transfer }\end{array}$ & 1.823 .177 .097 .000 & 1.907 .792 .409 .000 & $4.64 \%$ \\
\hline Lain-lain & 135.000 .000 .000 & 469.674 .419 .533 & $247.91 \$$ \\
Pendapatan & & & \\
Daerah Yang Sah & & & \\
\hline
\end{tabular}

Journal of Governance and Local Politics (JGLP)

ISSN (online): 2684-9992, Vol. 1, No. 2, November 2019 


\begin{tabular}{|c|c|c|c|}
\hline Belanja & 2.335 .841 .443 .000 & 2.514 .666 .239 .392 & $7.66 \%$ \\
\hline Belanja Operasi & 1.487 .390 .962 .457 & 1.697 .025 .239 .158 & $15.65 \$$ \\
\hline Belanja Modal & 745.414 .218 .543 & 689.577 .436 .442 & $-7.49 \%$ \\
\hline $\begin{array}{c}\text { Belanja Tak } \\
\text { Terduga }\end{array}$ & 2.000 .000 .000 & 2.500 .000 .000 & $25.00 \%$ \\
\hline Transfer & 121.036 .262 .000 & 125.563 .563 .792 & $3.74 \%$ \\
\hline
\end{tabular}

Sumber: Badan Pengelolaan Keuangan, Pendapatan dan Aset Daerah (BPKPAD) Provinsi Maluku Utara

Pada anggaran pendapatan, kenaikan anggaran terutama bersumber dari peningkatan signifikan dari target Lain-lain Pendapatan Daerah yang Sah yang mencapai 247,91\% (Tabel 2.1). Kenaikan target Lain-lain Pendapatan Daerah yang Sah ini dikarenakan target pendapatan hibah meningkat lebih dari dua kali lipat dari tahun sebelumnya dan terdapat target pendapatan lainnya yang pada anggaran sebelumnya tidak dicantumkan. Disamping komponen Lain-lain Pendapatan Daerah yang Sah, komponen Pendapatan Asli Daerah (PAD) juga ditargetkan mengalami kenaikan mencapai 71,98\% dan peningkatan pendapatan transfer sebesar 4,64\%(Grafik 2.1). Pendapatan transfer adalah pendapatan yang didapatkan dari pemerintah pusat sesuai dengan aturan perundang-undangan yang berlaku. Secara struktur, pendapatan transfer ini masih menjadi sumber pendapatan terbesar pemerintah Maluku Utara yaitu sebesar 66,61\% pada APBD 2017, meskipun demikian pada tahun 2017 ini Pemerintah Provinsi Maluku Utara berupaya meningkatkan target Pendapatan Asli Daerah (PAD) dengan cara mengoptimalkan penyerapan pajak melalui elektronifikasi transaksi, mendorong pembayaran bagi hasil pertambangan yang selama ini tertunda, serta peningkatan pemasukan dari sector perikanan. 


\section{Grafik 1.}

\section{Perubahan Struktur APBD Maluku Utara}

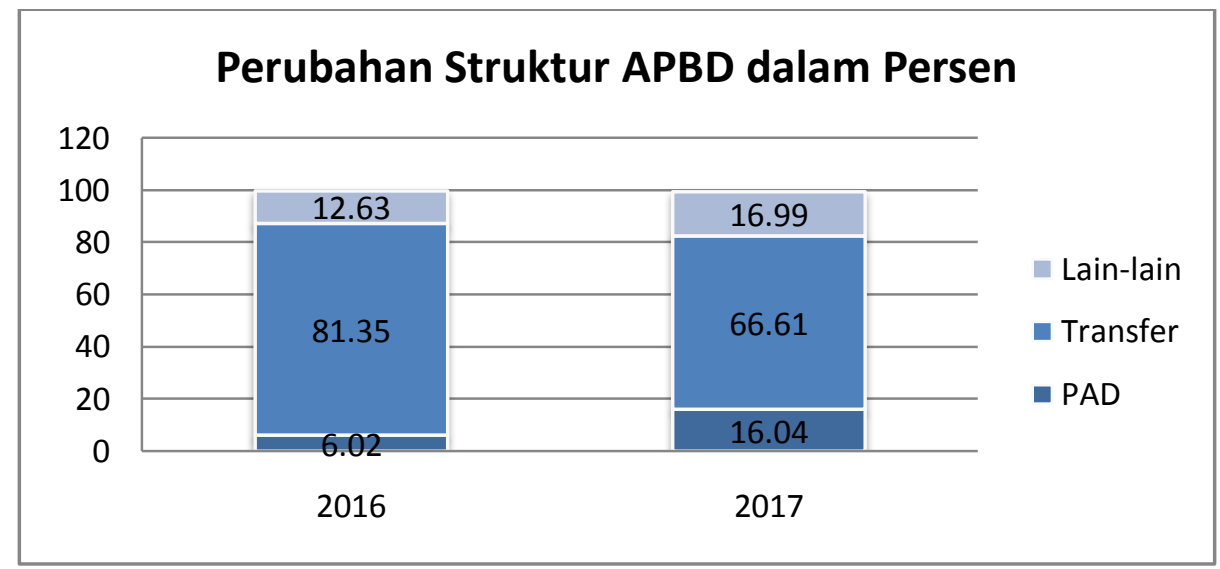

Sumber: Badan Pengelolaan Keuangan, Pendapatan dan Aset Daerah (BPKPAD) Provinsi Maluku Utara

Kenaikan juga terjadi pada anggaran belanja seiring adanya kenaikan pada anggaran pendapatan. Kenaikan terjadi terutama pada pos belanja operasional sebesar 15,65\% (Grafik 2.2). Kenaikan pada nominal belanja operasional tersebut terjadi utamanya karena terdapat peningkatan cukup signifikan pada pos belanja pegawai sebab adanya pengangkatan pegawai honorer menjadi pegawai tetap, timbulnya pos belanja bunga untuk pelunasan kewajiban kepada pihak ketiga, serta peningkatan pada pos belanja bagi hasil kepada pemerintah kabupaten/kota. Secara struktural, pangsa dari anggaran belanja mengalami perubahan yang cukup signifikan, dimana pos belanja operasional meningkat pangsanya menjadi sebesar 67,49\%, sementara pos belanja modal turun pangsanya menjadi sebesar $27,42 \%$. 
Grafik 2.

Perubahan Struktur Akun Belanja Maluku Utara

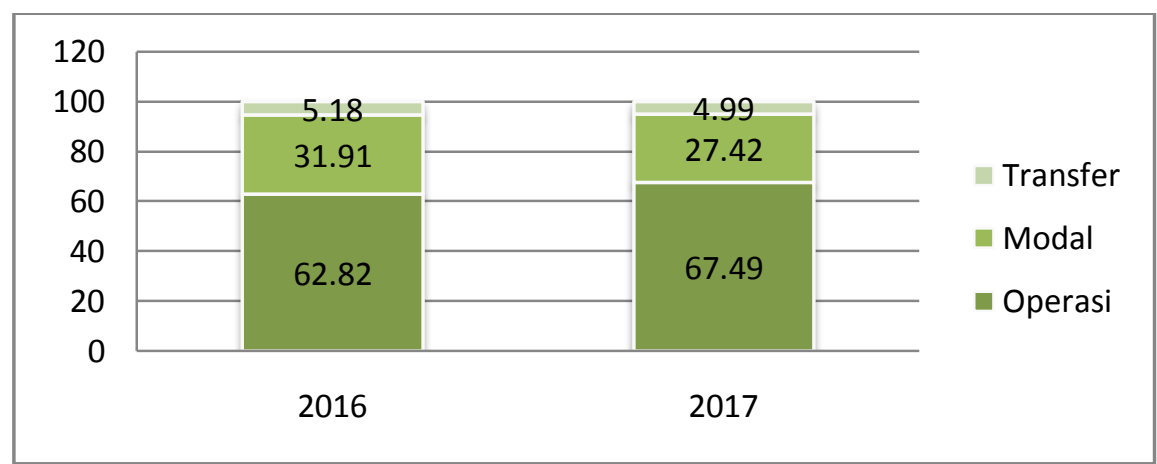

Sumber: BPKPAD Provinsi Maluku Utara, 2019

\section{Realisasi APBD Maluku Utara}

Jumlah total realisasi pendapatan Pemerintah Provinsi Maluku Utara pada triwulan IV 2017 sebesar Rp2.158,19 miliar (Grafik 2.3). Dari sisi nominal, jumlah ini meningkat 55,18\%. Peningkatan ini terutama terjadi seiring peningkatan PAD dan Dana perimbangan yang dipengaruhi oleh membaiknya kinerja sektor pertambangan dan industri pengolahan Maluku Utara, Peningkatan ini diiringi dengan kenaikan dari sisi pencapaian anggaran, realisasi tahun ini mencapai 75,35\%, lebih tinggi dibanding triwulan IV 2016 yang terealisasi sebesar 64,33\%.

Berdasarkan komponen pembentukannya, realisasi tertinggi pendapatan Pemerintah Provinsi Maluku Utara berasal dari Dana Perimbangan yang realisasinya sebesar 98,56\%. Sementara realisasi Pendapatan Asli Daerah (PAD) pada triwulan IV 2017 masih sebesar 42,95\%. Masih terbatasnya sumber Pendapatan Asli Daerah (PAD) di Provinsi Maluku Utara, menyebabkan struktur APBD Pemerintah Provinsi, Pemerintah Kabupaten dan Kota di Maluku Utara, khususnya di sisi pendapatan, masih didominasi oleh Dana Perimbangan dari Pemerintah Pusat. 


\section{Grafik 3.}

\section{Realisasi Pendapatan APBD Tahun 2016 dan Tahun 2017}

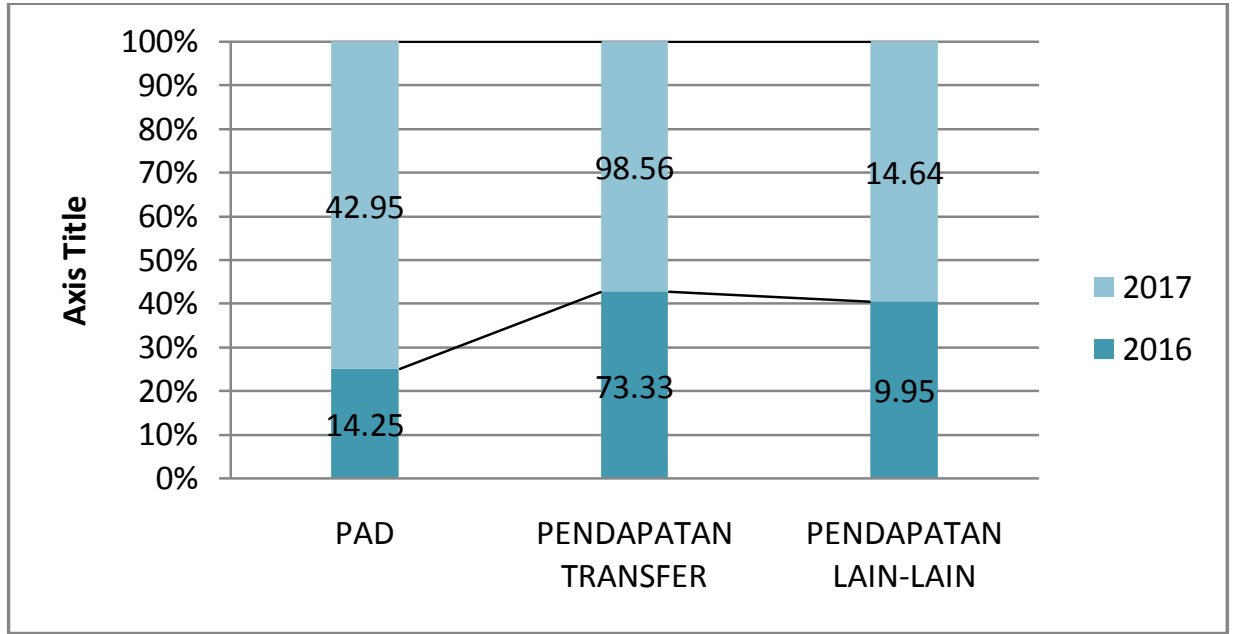

Sumber: BPKPAD Provinsi Maluku Utara, 2019

Secara umum realisasi komponen pendapatan pada triwulan IV 2017 lebih tinggi dibandingkan dengan dengan tahun sebelumnya. Realisasi PAD hingga akhir triwulan IV 2017 telah mencapai 42,95\%, pencapaian tersebut jauh lebih tinggi dari realisasi periode yang sama di tahun 2016 yang terealisasi sebesar 16,51\% (Grafik 2.4). Peningkatan tersebut didorong oleh realisasi pendapatan yang berasal dari pajak kendaraan bermotor, pajak BBM, dan pajak air permukaan yang terealisasi cukup tinggi pasca penerapan transaksi non tunai, sehingga risiko kebocoran dapat semakin diminimalisir. Selain itu, pemasukan dari retribusi daerah juga terealisasi cukup tinggi.

\section{KESIMPULAN}

Hasil Laporan atas laporan keuangan pada Pemerintah Provinsi Maluku Utara tahun 2018 memuat penurunan opinji Wajar Tanpa Pengecualian (WTP). Menurut penilaian BPK ditemukan pemeriksaan yang mengandung indikasi awal kecurangan disajikan dalam LHP tanpa menjelaskan secara mendetail dugaan kecurangan tersebut. Namun Pemeriksa lebih menitikberatkan penjelasannya 
kepada dampak temuan tersebut terhadap hal pokok/informasi hal pokok sesuai tujuan pemeriksaan.

Laporan pemeriksaan ditemukan Kelebihan pembayaran yang terjadi pada Pemprov Maluku Utara, namun atas pekerjaan tersebut belum dilakukan pelunasan pembayaran kepada rekanan. Terjadi pemasalahan pada 3 proyek pembanguna PUPR sebesar 3,58 miliar serta Kekurangan penerimaan atas penggunaan langsung penerimaan Pajak Kendaraan Bermotor (PKB) dan Bea Balik Nama Kendaraan Bermotor (BBNKB) pada Pemprov Maluku Utara sebesar Rp1,87 miliar. Namun keterlambatan pembyaran utang pemerintah provinsi dibayarkan kepada pihak ketiga secara bertahap.

DPRD Provinsi Maluku Utara dan BPK melakukan pembahasan Pemeriksaan Dengan Tujuan Tertentu (PDTT) menghasilkan delepan poin kesepakatan untuk dilaksanakan oleh Pemerintah Provinsi Maluku. DPRD berpandangan bahwa defisit APBD tahun anggaran 2016 dan 2017 melebihi batas maksimal defisit yang dipersyaratkan, sementara kemampuan penerimaan pembiayaan daerah dipastikan tidak dapat membiayai defisit APBD sehingga berpotensi terjadinya siklus utang daerah yang tidak berkesudahan. Untuk menyelesaikan masalah ini, Pansus merekomendasikan kepada Pimpinan DPRD untuk berkoordinasi dan minta petunjuk di Kementerian Keuangan dan Kementrian Dalam Negeri RI.

\section{ACKNOWLEDGEMENT}

Ucapan terima kasih sebesar-besarnya kepada Kemenristek yang telah mendanai Penelitian dengan skema Penelitian Dosen Pemula (PDP) DRPM 2018.Pendanaan penelitian sangat membantu untuk meningkat publikasi serta penelitian dosen. Terima kasih juga kepala Lembaga Penelitian, Pengabdian dan Publikasi (LP3M) Universitas Muhammadiyah Maluku Utara yang telah bekerja keras sehingga Penelitian Dosen Pemula bisa dilaksanakan sampai selesai. Para 
dosen Prodi Ilmu Pemerintahan yang telah memberikan fasilitas serta jalan selama penelitian berlangsung.

\section{REFRENSI}

23, U. N. (2014). UU No. 23 Tahun 2014 tentang Pemerintah Daerah. p. Bab 1.

Abdul, H. (2014). Manajemen Keuangan Sektor Publik problematika penerimaan dan pengeluaran pemerintah. Jakarta: Salemba Empat.

Abdul, H., \& Muhammad, K. S. (2016). Teori, Konsep, dan Aplikasi Akuntansi Sektor Publik dari Anggaran hingga Laporan Keuangan dari Pemerintah hingga Tempat Ibadah. Jakarta: Salemba Empat.

BPK, R. (2017). Badan Pemeriksa Keuangan RI. Jakarta: Lampiran BPK.

BPK, R. (2012, Agustus). Badan Pemeriksa Keuangan, Korupsi Tidak Wajar, Tanpa Pengecualian. Retrieved from bpk.ri: http://www.bpk.go.id/news/korupsi-tidak-wajar-tanpa-pengecualian.

BPK, R. (15, Februari 2017:60). Badan Pemeriksa Keuangan, Lampiran IV Peraturan BPK RI Nomor 1 Tahun 2017 Standar Pemeriksaan Keuangan Negara $\quad$ PSP 20 Retrieved from bpk/ri: http://www.bpk.go.id/page/standar-pemeriksaan-keuangan-negara.

Hendra, K. (2011:33-34). Partisipasi Masyarakat dalam Pengelolaan Keuangan. Bandung: Alumi.

Ikhwan, F. (2016). Pengawasan Keuangan Negara: Pemeriksaan Keuangan Negara: Pemeriksaan Keuangan Negara Melalui Auditor Internal \& Eksternal serta DPR, . Malang: Intrans Publishing.

Kriyantono, R. (2007). Teknik Praktis Riset Komunikasi. Jakarta: Kencana Prenada Media Group.

Mardiasmo. (2001:205). Pengawasan, Pengendalian, dan Pemeriksaan Kinerja Pemerintah Daerahdalam Pelaksanaan Otonomi Daerah. Yogyakarta: PT Andi. 
Marno, W. (2017:201). Politik Anggaran Eksekutif dan Legislatif Pada Pembahasan APBD Buru selatan 2015. JURNAL OF GOVERNMENT - JOG , 179-204.

Marno, W., \& Suranto. (2016:139). Pola Relasi Eksekutif Dan Legislatif Pada Penyusuna Legislasi Daerah. JGPP UMY , 111-140.

Moleong, J. L. (1994). Metodologi Penelitian Kualitatif. Jakarta: Raja Grafindo Persada.

Nurlan, D. (2008:133). Akuntansi Keuangan Daerah (Akuntansi Sektor Publik). Jakarta: Indeks.

PP No 21, 2. (2011). Peraturan Menteri dalam Negeri tentang Pemerintah Daerah No 21 Tahun 2011. Jakarta: Kemendagri.

Sadu, W., \& Riyani, O. (2003:93). Etika Hubungan Legislatif dalam Pelaksanaan Otonomi Daerah . Bandung: Fokus Media.

Saidi, D. M., \& Eka, M. D. (2007). Hukum Keuangan Negara Teori dan Praktek. Jakarta: Raja Grafindo Persada.

Syaputra, A. (2016). “Analisis Faktor-Faktor Yang Mempengaruhi Penyerapan Anggaran Dengan Perubahan Anggaran Sebagai Variabel Moderating Pada Pemerintah Kabupaten/Kota di Sumatera Utara (2011-2014)”. Medan: Fakultas Ekonomi dan Bisnis Sumatra Utara.

UU No 23, 2. (2014:152). Undang-Undang Nomor 23 Tahun 2014 Tentang Pemerintah Daerah. Jakarta: Kemendagri. 